Zoology and Comparative Anatomy, Botany, Geology, Geography, and Political Economy, and certain other needs will be served there. The Departments moving out of the old buildings of the College will set free accommodation much needed by the Faculty of Arts and by the Libraries. The College has also received a great benefaction for the endowment of the Department of Zoology and Comparative Anatomy from the Rockefeller Foundation. The benefaction amounts to $£ 88,000$, and must be devoted to the advancement of research. This gift follows other benefactions by the Rockefeller Foundation, which have made possible the building of the new Department of Anatomy and Embryology and the provision of endowments for that Department and the Departments of Physiology and Pharmacology.

\section{British Industries Fair}

THE eighteenth Biitish Industries Fair, which will open in London and Birmingham on Feb. 22, will be the largest and most representative display of British manufactured goods that has yet been organised. Last year exceeded all previous efforts, and this year marks a further advance. Following the practice of last year, the Fair will consist of two sections, the London Section and the Birmingham Section. In London the exhibits of the lighter trades and the specifically Empire exhibits will be held at Olympia; the White City will accommodate the display of textiles and clothing, which for the first time will represent all branches of the textile industry. At Castle Bromwich, Birmingham, there will be exhibits mainly of hardware, house equipment, and engineering, and, out-oi-doors, an exhibition of agricultural implements and of plant for light railways, quarrying, and roadmaking. The total frontage of the stands in all sections of the Fair will amount to approximately 16 miles. The total number of exhibitors will be 2305 , of which 1150 will exhibit their products at Olympia, 130 at the White City, and 1025 at Castle Bromwich. Of the new trade groups that have co-operated in this organised effort to exhibit the variety and extent of British manufactures, mention may be made of the oil section, and of the section for mining, quarrying, and roadmaking plant. The former will provide working exhibits of the latest oil-fired plant, and the latter will give a demonstration of the actual construction of a road. We hope to give, in a subsequent issue, a review of some of the chief features of the Fair.

\section{Second Dynasty Burial Rites at UI}

Mr. LeONARD WOOLLEY's first report on the current season's work at Ur, which appeared in the Times for Feb. 12, chronicles inter alia the discovery of a burial of a type "quite out of the ordinary". It has the additional interest that it belongs to the Second Dynasty of Ur, about 2800 B.C., a period and dynasty about which at present nothing is known. The Joint Expedition of the British Museum and the Museum of the University of Pennsylvania is now engaged in endeavouring to trace the earlier history of the sacred area on which stands the famous ziggurat of the Third Dynasty. In the first month's work the complete ground plan of a range of buildings on the north-west side has been brought to light. The buildings belong to the First Dynasty. The burial to which reference has been made was not discovered here, but in the course of excavating a patch of ground between the predynastic cemetery and the mausoleum of Bur Sin. Eighteen people were found buried at the foot of a rectangular shaft originally at least $20 \mathrm{ft}$. deep, but of which the bottom is now $30 \mathrm{ft}$. below the surface. All the bodies, which were bedecked with gold ornaments and beads, had been buried independently, although the burials were contemporary, and the same elaborate ritual had served them all. Above the graves a clay floor had been spread, and on this were fireplaces and a brickwalled enclosure containing traces of food. Above this were two floors, at different levels, with altars, and the shaft was closed finally with rubble and brick packing. Evidently, Mr. Woolley notes, the burial had been by stages, each marked by ceremonies of fire and sacrifice.

\section{Co-operation in Archæological Research in France}

THE Smithsonian Institution announces the completion of an agreement with the University of Toulouse, whereby the two bodies will co-operate for a period of ten years in the excavation of the cave of Marsoulas in the Haute-Garonne among the foothills of the Pyrenees, The cave is the property of the University, and is alrearly well known to archæologists for its polychrome paintings and wall engravings of palæolithic age. It was first investigated by archæologists in 1886-87, but after that it was comparatively neglected until recent excavation by $\mathbf{M r}$. J. Townsend Russell of the Division of Old World Archæology of the Smithsonian Institution. The cavern is about thirty metres in extent, but galleries now closed by clay infiltration suggest that at the time of its occupation by palæolithic man it may have afforded more extensive accommodation than at present. It is hoped that it may be possible to open up these galleries. By the time the agreement expires, the cave should be cleared completely. In the meantime the terms of the agreement may be extended to cover other investigations, possibly so far afield as the French Near East and Africa.

\section{Recent Excavation in the Marsoulas Cave}

Excavatron in the Marsoulas Cave during the past season by Mr. Russell on behalf of the Smithsonian Institution has already produced results of importance, which promise well for the future of the joint undertaking. Two ancient hearths were found, of which the upper yielded artefacts typical of the Magdalenian period. Just below was an Aurignacian hearth with typical knives, scrapers, points and decorative pendants of flint and bone. An unexpected find was a triton shell, which must have come from warm water then far to the south, probably from Africa. The technique of one of the numerous wall-paintings observed is described as unique. The animal form had been produced by the thumb of the painter, which had been dipped in the wet pigment and then pressed on the wall. The paintings of the Marsoulas Cave are singular in the fact that they are near the entrance

$$
\text { No. 3251, VoL. 129] }
$$


instead of in the far recesses of the Cave as is more usual. Their excellent state of preservation suggests that the entrance of the cave must have been blocked by an obstruction for a very long period after the close of the palæolithic age.

\section{Cereals for Spring Sowing}

THE selection of the best varieties of cereals for spring sowing is always a question of importance for the farmer. To meet this need, the National Institute of Agricultural Botany, Cambridge, has issued a leaflet (Farmer's Leaflet, No. 2) describing the varieties most suitable for use in the Midlands, east, and south of England, the recommendations being based on tests carried out at a number of trial stations. The sowing of spring wheat is not, in general, advocated, but of the varieties available, Little Joss is suggested for February and Red Marvel or Al for early March sowings. The choice of oats is, however, much wider. Victory is one of the best all-round varieties, useful both for sale and feeding. Star, an oat similar, on the whole, to Victory, has the additional advantage of a thinner husk and a better standing straw, and is, therefore, preferable on highly fertile soils. Golden Rain and Golden Rain II. also deserve consideration when the crop is intended for feeding on the farm, since the colour of the grain is apt to affect the market price adversely. Marvellous is a further variety which usually gives heavy crops, but it is only suitable for early February sowings. As regards barley, the choice lies between the well-established Plumage and Spratt. Archers and the new variety recently produced by Dr. Beaven, called Golden Archer. The latter is of the Spratt-Archer type, with similar malting quality, but the yield is rather better. For unusually late sowings, the early ripening Victory is suggested as the most suitable. Early sowing of all spring cereals is regarded as of the utmost importanice, irrespective of the variety chosen. In view of the bad harvest conditions of 1931 , farmers are advised to pay special attention to germination. The Official Seed Testing Station, Cambridge, undertakes germination tests at the nominal fee of $6 d$. per sample.

\section{Selection of Sugar Beet Seed}

THE question of the selection of sugar beet seed will soon be receiving the attention of farmers, now that most factories have fixed sugar beet prices for 1932 . The results of the exhaustive trials carried out by the National Institute of Agricultural Botany, Cambridge, in recent years, have been reviewed in the light of the new prices, and it can be confidently said that on most soils the heavy yielding (or E types) will pay the farmer better than the high-sugar-content (or $Z$ ) types. For general cultivation, Kleinwanzleben $\mathrm{E}$ or $\mathrm{N}$, Dippe E, Dobrovice, Hoerning R.R., and Zapotil I can all be recommended; Marsters and Johnston's Perfection should be chosen for early sowing, and on very rich land either of these two or Kuhn P. A Ieaflet describing these strains can be obtained, free of charge, from county organisers, or the Institute, to which application can also be made by those desirous of advice or further information.

No. 3251, VoL. 129]

\section{Forestry in Kenya}

Tre Annual Report of the Kenya Forest Department for the year ending Dec. 31, 1930, affords pleasurable reading for all those interested in the progress of forestry conservation and development in the Empire. The whole Colony enjoyed good rains, and a record acreage of new plantations, 4429 acres, was made. Excellent growth both of the new and old plantations was recorded, and there were no forest fires of any consequence. The economic slump, as is a common experience in forestry operations, resulted in a considerable drop in the revenue from timber and from the sale of young trees and seeds. For the first time the revenue from firewood actually exceeded that from timber. This factor alone would justify the far-seeing policy of the Colony's administrators in supporting a correct forest administration. It is of interest to note that the management of the intensively worked forests of the Nairobi District was placed on $a_{0}$ satisfactory basis during the year by the completion of detailed working plans. The Chinese tung oil tree, Aleurites Fordii, has been previously alluded to in NATURE, and it was mentioned at the time that experiments were being carried out to ascertain the possibilities of growing the tree commercially in several of the Colonies. Great interest is being shown in this tree by farmers in Kenya, and the Forest Department has acted as agent in the distribution of the seed. A fow experimental trees have been planted, since it was first grown in the Department's arboretum in 1922, at practically every forest station, to test the suitability of the various districts, but the trees are as yet too young to give definite indications.

\section{A Modern Telephone Cable}

IN January 1931 a telephone service was inaugurated over a new submarine cable spanning the hundred miles between Key West, United States, and Havana, Cuba. The new eable is the longest deep-sea telephone cable in the world, and it is unique in having neither intermediate repeaters nor inductive loading. A paper describing its engineering characteristics was read by H. A. Affel, W. S. Gorton, and R. W. Chesnut at the winter convention, held in January, of the American Institute of Electrical Engineers. 'The new cable can operate at a frequency of 28,000 cycles a second, which is about eight times faster than ordinary cables. The feature of the new cable which has made this great improvement possible is the use of paragutta, the new insulating material invented at the Bell Telephone Laboratories. There are three telephone channels in the cable, obtained by an adaptation of the ordinary carrier apparatus used for long distance transmission over open wire lines. There are six frequency bands, one for each direction in the three channels. The largest skin effect occurs in the central conductors, but the effect is also noticeable in the thin return copper tapes. Elaborate precautions were taken to prevent 'noise' intruding in the speech circuit. Frequency limiting filters were introduced into several neighbouring circuits and proved effective. If traffic requirements grow so that more facilities are required, a higher frequency range can be employed 